\title{
REVIEW
}

\section{Molecular underpinnings of enzalutamide resistance}

\author{
S Prekovic', T Van den Broeck2,3, S Linder'1, M E van Royen4,5, A B Houtsmuller,5, F Handle², S Joniau³, \\ W Zwart1,6,* and F Claessens ${ }^{2, *}$
}

'Division of Oncogenomics, Oncode Institute, The Netherlands Cancer Institute, Amsterdam, The Netherlands 2Laboratory of Molecular Endocrinology, KU Leuven, Leuven, Belgium

3Department of Urology, University Hospitals Leuven, Leuven, Belgium

${ }^{4}$ Department of Pathology, Erasmus MC, Rotterdam, The Netherlands

${ }^{5}$ Erasmus Optical Imaging Centre, Erasmus MC, Rotterdam, The Netherlands

${ }^{6}$ Department of Biomedical Engineering, Laboratory of Chemical Biology and Institute for Complex Molecular Systems, Eindhoven University of

Technology, Eindhoven, The Netherlands

Correspondence should be addressed to S Prekovic or F Claessens: s.prekovic@nki.nl or frank.claessens@med.kuleuven.be

*(W Zwart and F Claessens share senior authorship)

\begin{abstract}
Prostate cancer ( $\mathrm{PCa}$ ) is among the most common adult malignancies, and the second leading cause of cancer-related death in men. As PCa is hormone dependent, blockade of the androgen receptor (AR) signaling is an effective therapeutic strategy for men with advanced metastatic disease. The discovery of enzalutamide, a compound that effectively blocks the AR axis and its clinical application has led to a significant improvement in survival time. However, the effect of enzalutamide is not permanent, and resistance to treatment ultimately leads to development of lethal disease, for which there currently
\end{abstract}

\author{
Key Words \\ - enzalutamide \\ - abiraterone \\ - resistance \\ - androgen receptor \\ - glycolysis \\ - hexosamine biosynthesis \\ - autophagy \\ - cancer \\ - prostate cancer \\ - AKR3C1 \\ - Wnt \\ - IL-6 \\ - mCRPC \\ mutations
} (2018) 25, R545-R557

\section{Introduction}

Metastatic prostate cancer (PCa) is an incurable disease with relative 5-year survival rate of 29\% (Sartor \& de Bono 2018). While current therapies are effective at slowing down progression of the disease, eradication of metastatic cancer is currently not achievable.
Several approaches to treat this lethal disease exist, including chemotherapy and targeted therapy (Cornford et al. 2017). Blocking the androgen receptor (AR), a main driver of disease progression is a preferred therapeutic strategy. Currently, enzalutamide is one of the most 
frequently used antiandrogens in treatment of the advanced disease. However, antiandrogen treatment is inevitably counteracted by a selection process, resulting in the emergence of resistant tumor clones. Prostate cancer cells have various ways to escape the shackles of AR-directed therapies, even the strongest enzalutamide treatment. This review will focus on specific resistance mechanisms discovered in vitro, but anticipated to occur in the clinics and vice versa.

\section{AR mutations as mediators of enzalutamide resistance}

Gain-of-function mutations in the $A R$ gene are almost exclusively found in $\mathrm{MCRPC}$ and not in primary disease (Grossmann et al. 2001). While nucleotide substitutions most frequently occur within the exon coding for the ligand-binding domain, mutations in other regions of the $A R$ gene have been reported (Watson et al. 2015, Nadal et al. 2017, Prekovic et al. 2017). For example, N-terminal domain and hinge region mutations have been shown to change the activation potential of the AR. A small deletion between positions 388 and 390 resulted in the loss of a sumoylation site, which is also known to potentiate AR activity in vitro (Callewaert et al. 2004). Furthermore, several mutations in the hinge region also seem to result in gain of function (Haelens et al. 2007).

As mentioned earlier, most frequently, changes are located within the ligand-binding pocket (LBP). These can cause promiscuity of the receptor for alternative ligands or alter the mode of action of antiandrogens resulting in their conversion to potent activators of the receptor (Grossmann et al. 2001). The first clinically relevant $A R$ mutation in $\mathrm{PCa}$ was detected in a metastatic specimen of a patient who underwent flutamide treatment (Taplin et al. 1999). Following that discovery, various other mutations in the AR LBP have been detected in treatmentresistant mCRPC (Coutinho et al. 2016).

Molecular screens designed for detection of $A R$ mutations that cause the antagonist-to-agonist switch for enzalutamide led to description of F877L, a mutation that was reported to convert enzalutamide to a partial agonist of the AR (Balbas et al. 2013, Joseph et al. 2013, Korpal et al. 2013). However, this mutation is yet to be found in patients who progressed on enzalutamide treatment. Strikingly, for now a single mutation able to convert enzalutamide to a full agonist has not been identified, despite sequencing a rather large number $(n=72)$ of enzalutamide-treated patients (Robinson et al. 2015).

However, several double mutant ARs which convert enzalutamide to a strong partial agonist were reported by the Vancouver Cancer Agency (Azad et al. 2015, Lallous et al. 2016, Wyatt et al. 2016). In their cohort, enzalutamide treatment led to the emergence of F877L/T878A and M896V/S889G double mutants, which were associated with resistance (Fig. 1). A detailed molecular analysis of the F877L and the double mutant F877L/T878A revealed that the second mutation is essential for enhancing the $\mathrm{N} / \mathrm{C}$ interactions, co-regulator interactions and transactivation (Prekovic et al. 2016). The second mutation expands the LBP and potentially induces repositioning of helix 11 and helix 12 (H12) toward the LBP, in turn facilitating the transition into the agonistic conformation of the receptor (Prekovic et al. 2016). This mutant AR is still inhibited by Abiraterone Acetate, Epi-001 and Galaterone (Attard et al. 2009, Andersen et al. 2010, Njar \& Brodie 2015). For the M896V/S889G double mutant, it is proposed that the M896V also leads
A

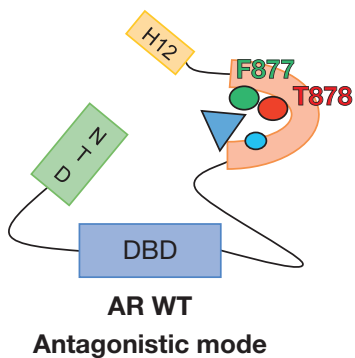

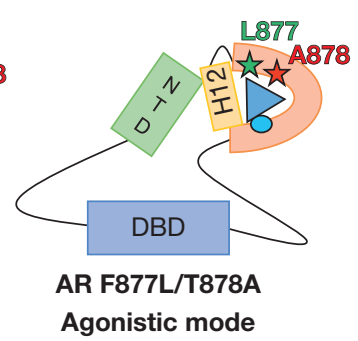

B

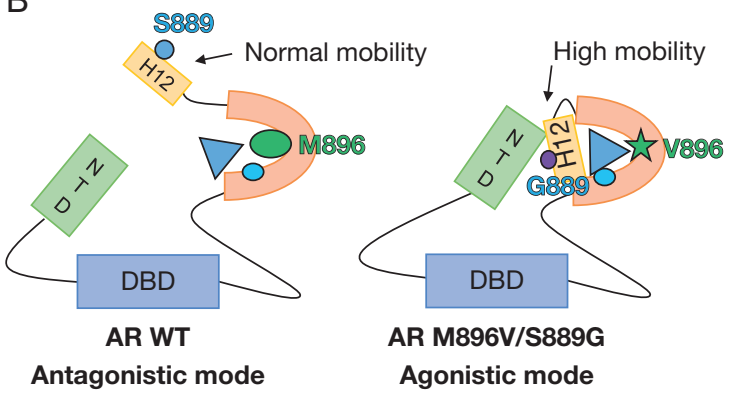

Figure 1

Androgen receptor mutations may cause antagonist-to-agonist switch for enzalutamide. (A) Double-mutant F877L/T878A AR has enhanced affinity for enzalutamide, an increase in N/C interactions, co-regulator interactions and transactivation upon enzalutamide binding. (B) Changes in LBP volume and mobility of $\mathrm{H} 12$ that occur in S889G/M896V AR double mutant convert enzalutamide to a partial agonist of the receptor. 
to the expansion of the LBP, while the introduction of a flexible glycine side chain might increase the mobility of H12 and facilitate the formation of activation-function 2 (AF2) (Lallous et al. 2016). The single mutant remains inhibited by enzalutamide, while for the double mutant AR enzalutamide is a partial agonist.

In conclusion, mutational events in the $A R$ gene that lead to conversion of enzalutamide to an agonist are rare and do not contribute to resistance in the majority of the patients.

\section{AR splice variants}

While it is certain that hormone therapy response and resistance in PCa are marked by the emergence of truncated AR splice variants (Antonarakis et al. 2014, Seitz et al. 2017), the functional mode of these AR variants is still under debate (Watson et al. 2010, Li et al. 2013, Luo et al. 2017). The AR variants are structurally diverse; however, most of them lack parts or the whole ligand-binding domain resulting in the inability of ligands to control their function. However, there are conflicting reports on whether truncated ARs initiate the same transcriptional program as the full-length $\mathrm{AR}$ and whether they can activate the expression of AR target genes without the presence of full-length protein (Fig. 2A).

Truncated ARs could very well serve as markers of response and resistance to therapy in advanced PCa (Antonarakis et al. 2014, Cao et al. 2014). Both in experimental and clinical setting, enzalutamide treatment indeed induces the expression of truncated ARs. Moreover, the splice variants are expressed at high levels in cell lines resistant to the enzalutamide. The truncated ARs are suggested to drive resistance to enzalutamide by recapitulating the AR signaling even when the fulllength AR is blocked (Li et al. 2013). Interestingly, recent data suggest that suppressing AR splice variants can restore sensitivity to enzalutamide in xenograft models, implying that this could be used as a strategy to overcome antiandrogen resistance (Luo et al. 2017, Tummala et al. 2017).

\section{Glucocorticoid receptor takeover}

There is a high similarity of molecular mechanisms behind DNA binding by the AR and the other oxosteroid hormone receptors (glucocorticoid, estrogen, progesterone and mineralocorticoid receptor) (Fig. 2B) (Schoenmakers et al. 1999, 2000, Shaffer et al. 2004, Denayer et al. 2010). For that reason, it is conceivable that they are interchangeable in some cases of enzalutamide resistance. In PCa cell lines, the glucocorticoid receptor (GR) can indeed recapitulate part of the AR transcriptional program under castrate conditions and promote growth (Sahu et al. 2013). Furthermore, Arora et al. (2013) demonstrated that GR is able to support the cell cycle of PCa cells when the AR is antagonized by enzalutamide. Moreover, they showed an increase in GR expression in tumor samples from patients receiving enzalutamide therapy. Treatment with enzalutamide is also accompanied by loss of an enzyme (11 $\beta$-HSD2) that inactivates cortisol, further boosting GR activity and enzalutamide resistance (Li et al. 2017). The possible role of the GR as an oncogene in PCa is suggested by the post hoc analysis of the AFFIRM study, which has shown that patients co-treated with glucocorticoids have inferior clinical characteristics and OS rate in both placebo- (9.3 vs 15.8 months) and enzalutamide-treated (12.3 vs OS not reached) groups (Montgomery et al. 2014).
A

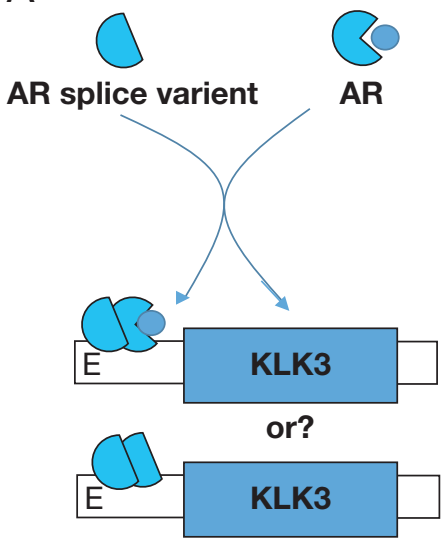

B

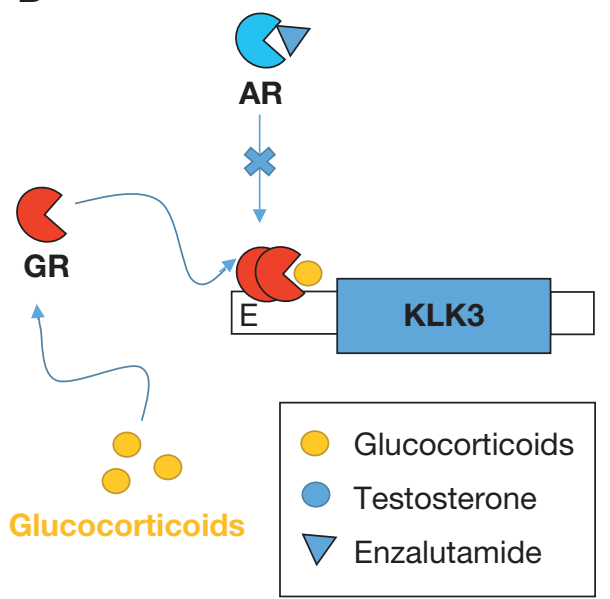

Figure 2

Androgen receptor splice variants and glucocorticoid takeover may mediate enzalutamide resistance. (A) AR splice variants without the ligand-binding domain are not under the control of the ligand, and may act either in pair with the full-length receptor or as homodimers to drive the growth despite presence of antiandrogens targeting the ligand-binding domain. (B) Glucocorticoid receptor may hijack the androgen response elements and drive the growth of prostate cancer when the AR is inhibited by enzalutamide. E, element. 
Surprisingly, a tumor suppressor role of GR has also been described elaborately. Glucocorticoids suppress tumor angiogenesis (Yano et al. 2006) and inhibit PCa cell growth in vitro (Nishimura et al. 2001, Yemelyanov et al. 2007). Furthermore, several clinical studies have shown that glucocorticoid co-treatment is beneficial for mCRPC patientsin differentsettings (Storlieetal. 1995, Tannocketal. 1996, Fosså et al. 2001, De Bono et al. 2011, Ryan et al.2013). Possibly, whether the GR acts as an oncogene or a tumor suppressor gene might be influenced by interacting partners and/or chromatin remodeling proteins. For instance, one could hypothesize that pioneering factors such as FOXA1 might be involved, as it is known to regulate $\mathrm{AR}$ and GR transcriptional activity in a cell type-specific manner (Sahu et al. 2013).

\section{Intratumour production of androgens mediated by AKR1C3 enzyme}

Intratumour production of androgens is able to drive PCa progression and resistance toward androgen deprivation (Locke et al. 2008). Increase in expression of genes involved in androgen biosynthesis has been observed after ADT and antiandrogen treatment (Locke et al. 2008, Cai et al. 2011, Liu et al. 2015). One of these enzymes, AKR1C3, is an emerging therapeutic target in PCa and is upregulated in advanced disease (Fig. 3) (Fung et al. 2006, Hamid et al. 2012). The AKR1C3 is an NADPH-dependent

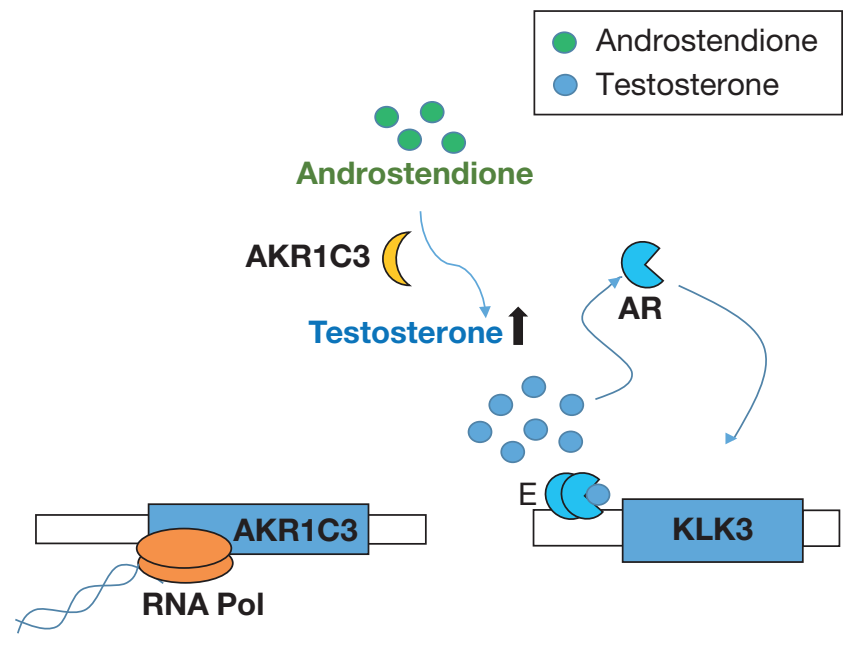

Figure 3

Enzymes involved in steroidal biosynthesis mediate intratumoral production of testosterone. Increase in expression of AKR1C3 gene leads to increase in conversion of androstenedione to testosterone within the cancer cells; this allows reactivation of the AR signaling despite the presence of antagonists. reductive enzyme that converts weak androgens (DHEA and androstenedione) to more potent androgens in the prostate (testosterone and DHT) (Lin et al. 1997). Besides that, AKR1C3 is also responsible for synthesis of several prostaglandins, which could also drive tumor progression (Matsuura et al. 1998, Sales et al. 2004). Evidence for a role of AKR3C1 in advanced PCa has been found in both cell line models and clinical samples of advanced disease. AKR1C3 is upregulated in PCa cell lines when grown in androgens-depleted conditions and enzalutamide (Pfeiffer et al. 2011). Furthermore, in xenograft models, it was shown that addition of AKR1C3 substrate led to an increase in transcription of KLK3 gene, which was abrogated by a selective blocker of the AKR1C3 enzyme (indomethacin) (Cai et al. 2011). Importantly, upregulation of AKR1C3 was associated with clinical progression and aggressiveness of CRPC tumors (Stanbrough et al. 2006, Wako et al. 2008). These data converge to the conclusion that AKR1C3 may be a driver of androgen biosynthesis and growth in advanced PCa. Inhibition of AKR1C3 by indomethacin was already seen to be able to increase sensitivity of cancer cells to several different compounds (Byrns \& Penning 2009, Verma et al. 2016). Recently, it was shown that this compound could re-sensitize enzalutamideresistant PCa cells to enzalutamide both in vitro and in vivo (Liu et al. 2015). These data suggest that combining enzalutamide with AKR1C3 inhibitors may be a potential therapeutic strategy. Two clinical trials are investigating the clinical benefit of indomethacin in locally advanced PCa (NCT02849990) and mCRPC (NCT02935205). Interestingly, it was recently described that intratumoral androgen profile differs between TMPRSS2-ERG-positive and -negative PCa (Knuuttila et al. 2018). The positive status was associated with increased DHT/testosterone ratios, suggesting that TMPRSS2-ERG status could be used to identify patients that may benefit from inhibitors targeting the DHT biosynthesis (Knuuttila et al. 2018).

\section{Shift to aerobic glycolysis}

Over 80 years ago, Warburg hypothesized that cancer is a metabolic disorder (Warburg \& Dickens 1930). While most types of normal cells produce molecules with highenergy bonds predominantly by using the oxidative decarboxylation of pyruvate, cancer cells shift toward glucose as the main source for ATP production and decrease mitochondrial respiration (Gatenby \& Gillies 2004).

The metabolism of the prostate epithelial cells is unique as it favors citrate production and secretion 
(Costello \& Franklin 2000). The Krebs cycle of these cells is altered and interrupted, resulting in low levels of citrate oxidation, diminished respiration and ATP production (Costello \& Franklin 2000, Dakubo et al. 2006). While in most cancer types there is an initial switch toward aerobic glycolysis (less energy-efficient process per glucose molecule), in primary prostate cancer ( $\mathrm{PCa}$ ), there is a restoration of the Krebs cycle, which results in more energy being produced per glucose molecule (Costello \& Franklin 1998, 2000). Fascinatingly, it seems that the PCa cells induce the Warburg effect in their neighboring stromal fibroblasts, which hence secrete lactate and pyruvate that can be used by cancer cells (Di Vizio et al. 2009). Furthermore, during the course of disease progression of $\mathrm{PCa}$, there is yet another metabolic shift leading to an increase in glycolytic flux and hypoxic signaling within the cancer cells, which are correlated with poor prognosis (Pertega-Gomes et al. 2015).

Shift toward or increase in flux of glycolysis has been observed in various types of drug-resistant cancer, as well as PCa resistant to enzalutamide (Cui et al. 2014, Bhattacharya et al. 2016). Overexpression of the NFkB family member p52 leads in PCa cells to an increase in glycolytic capacity and to enzalutamide-resistant phenotype in preclinical models (Fig. 4A) (Cui et al. 2014). High levels of p52 intensify the flux of both glycolysis and pentose phosphate pathway, leading to an increase in ATP production, which supports evasion of apoptosis and fast

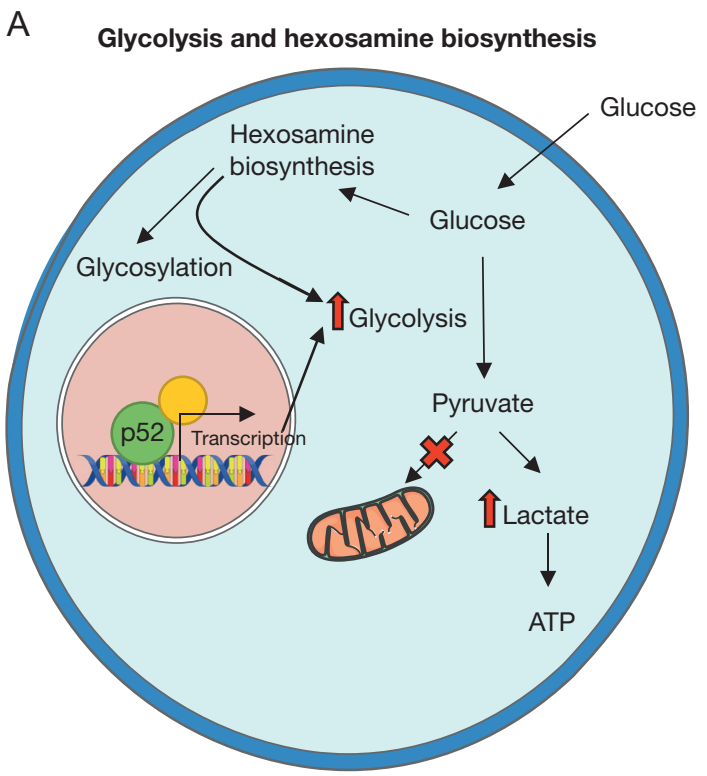

growth (Lunt \& Vander Heiden 2011, Cui et al. 2014). The shift to aerobic glycolysis can be achieved through other pathways besides the NFkB, such as IGF and PI3K signaling. Interestingly, these are recurrently mutated in CRPC (Roberts 2004, Robinson et al. 2015). Whether they contribute to resistance to antiandrogens via increase in aerobic glycolysis remains to be determined.

As there is multiple evidence that high glycolytic flux supports aggressiveness and drug resistance in $\mathrm{PCa}$, targeting glucose metabolism could be a therapeutic alley. Although not effective as monotherapy, 2-dexoglucose (a glucose analog that has the 2-hydroxyl group replaced by hydrogen) could be an alternative therapy in combination with radiation therapy or other drugs such as autophagy inhibitors (Dwarakanath et al. 2009, Gupta et al. 2009, Stein et al. 2010).

\section{Changes in the hexosamine biosynthetic pathway}

Recent reports have suggested that the hexosamine biosynthetic pathway (HBP) may play a role in antiandrogen resistance (Fig. 4A). This pathway accounts for about $2-5 \%$ of total glucose metabolism and is important for post-translational protein modifications, synthesis of glycolipids, proteoglycans and glycosylphosphatidylinositol anchors (Chatham et al. 2008, Munkley et al. 2016).

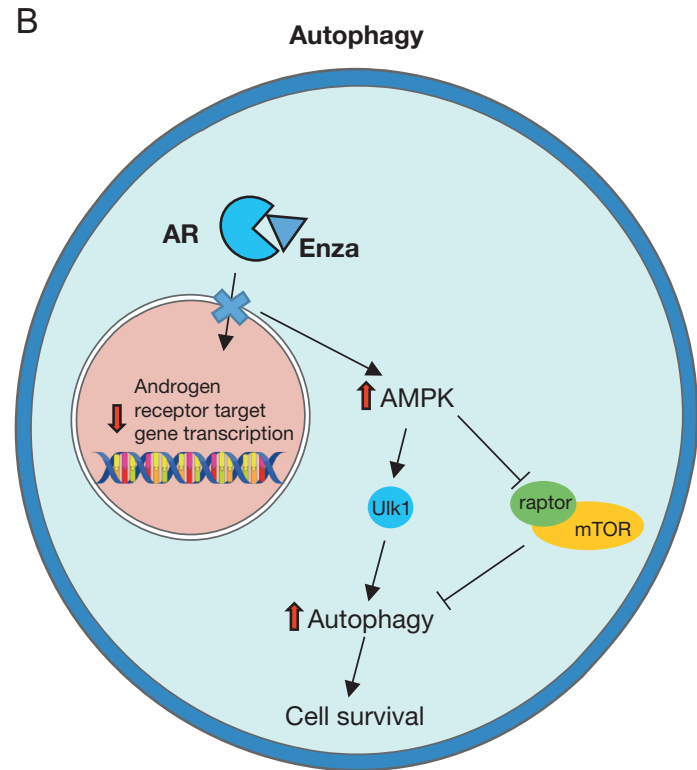

\section{Figure 4}

Metabolic alterations can lead to sustained growth and enzalutamide resistance. (A) Increase in glycolytic flux or hexosamine biosynthesis may drive cellular growth and annul the inhibitory effect of enzalutamide. (B) Androgen receptor inhibition leads to activation of AMPK, which regulates autophagy through inhibition of mTOR and activation of Ulk1, this in turn leads to cell survival. 
The HBP gives yield to UDP-GlcNAc, an amino-sugar conjugate that is used to modify proteins. Upregulation of crucial enzymes for UDP-glycosylation (OGT) and elevated glycosylation has been associated with poor prognosis, possibly by promoting metabolic reprogramming of $\mathrm{PCa}$ cells (Lynch et al. 2012, Kamigaito et al. 2014, Itkonen et al . 2016). The HBP was identified as one of the biochemical drivers of CRPC progression by mediating the metabolic re-wiring which supports cell growth (Itkonen et al. 2016, Kaushik et al. 2016). This pathway may also increase aerobic glycolysis which was seen to be one of the main characteristics of advanced PCa (Ma \& Vosseller 2014).

Recently, it was found that proliferation of CRPC-like cells can be inhibited by treatment with UDP-N-acetylglucosamine and the combination with enzalutamide led to further enhancement in efficacy of the therapy (Kaushik et al. 2016). Furthermore, inhibition of OGT, which is the enzyme that processes the UDP-GlcNAc, can also induce cancer cell death (Itkonen et al. 2016). Direct inhibitors that target the OGT enzyme have been developed (Trapannone et al. 2016), but their specificity should be enhanced before they can be tested in preclinical and clinical development.

\section{Autophagy}

Besides relaying on glucose metabolism, cancer cells can resort to autophagy for their survival. Similar to glycolysis, autophagy has been linked to drug resistance in several cancer types as well as in the survival of cells under unfavorable conditions including androgen deprivation (Li et al. 2008, Chhipa et al. 2011).

As discussed earlier, the PI3K/Akt signaling is altered in CRPC (Robinson et al. 2015). This signaling cascade results in activation of mTOR, which is an enticing therapeutic target as shown in preclinical settings (Sparks \& Guertin 2010). Multiple clinical trials with mTOR inhibitors have been conducted in the CRPC setting. In a systematic review, it was concluded that unfortunately these drugs lack efficacy in the clinical setting. However, the analysis also encouraged combined therapy with AR or PI3K inhibitors (Statz et al. 2016).

The AR is a negative regulator of autophagy and the inhibition of the AR stimulates autophagic activity in PCa cells (Boutin etal.2013). It was observed that cells insensitive to enzalutamide have high rates of autophagy (Fig. 4B). Inhibition of the AR leads to activation of autophagy through the activation of AMP-dependent protein kinase (AMPK) and suppression of mTOR signaling (Nguyen et al. 2014b). Combined therapy with enzalutamide and metformin was able to reduce tumor growth significantly more than either of them alone. These results suggest that using autophagy modulators such as metformin may be beneficial for patients on enzalutamide therapy or after the therapy (Nguyen et al. 2014b). Even though current clinical studies show that use of metformin has only a slight beneficial effect as monotherapy for advanced PCa (Rothermundt et al. 2014), the study to evaluate the effect of metformin in combination with enzalutamide was started (NCT02339168). To date, it was observed that combination of the two was well tolerated and the efficacy results supported continued study in patients with CRPC (Parikh et al. 2018). Other than that, a phase II clinical trial evaluating whether the combination of enzalutamide and metformin in CRPC patients progressing on ADT is better than enzalutamide alone (NCT02640534).

\section{Activation of canonical and non-canonical Wnt signaling}

Under normal physiological conditions, the Wnt pathway regulates growth of the embryo and maintenance of the stem cell populations (Logan \& Nusse 2004). There are two types of Wnt signaling: canonical and non-canonical. The canonical Wnt signaling is mediated by binding of Wnt ligand to Frizzled protein, which in turn stabilizes beta-catenin, the main executor of the canonical pathway (Logan \& Nusse 2004). The non-canonical Wnt signaling is an alternative mode in which beta-catenin is not involved (Gómez-Orte et al. 2013). Changes in both canonical and non-canonical Wnt signaling have been observed in CRPC. Mutations in CTNNB1 are frequent in metastatic samples (Chesire et al. 2000). Expression levels of Wnt-1 and beta-catenin were increased in $~ 80 \%$ of metastatic hormone refractory tumors (Chen et al. 2004). Recently, by looking at genome-wide changes in advanced metastatic tumors. Robinson et al. were able to identify Wnt pathway genomic alterations in $18 \%$ of the samples (Robinson et al. 2015). Interestingly, the Wnt pathway is also enriched in enzalutamide-treated LNCaP cells suggesting that it might compensate for AR loss and be involved in clinical progression under antiandrogen treatment (Lee et al. 2015).

The non-canonical Wnt signaling was found to be upregulated in human PCa supporting growth via potentiating AR signaling (Takahashi et al. 2011). In bone metastases of patients treated with antiandrogens, it was found that non-canonical Wnt might mediate castration resistance (Lee et al. 2014). Furthermore, non-canonical Wnt signaling is increased in circulating tumor cells from 
patients progressing under treatment with AR inhibitors. This activation seems to combat the negative effects of AR blockade (e.g. enzalutamide) and allows cells to continue proliferating (Miyamoto et al. 2015).

As the Wnt signaling is a crucial pathway in somatic stem cell homeostasis and regenerative processes after injury, therapies blocking this pathway could have serious adverse effects (Kahn 2014). However, due to progress in the development of Wnt inhibitors, there are several clinical trials that have just been completed or are currently running, e.g. trials for Vantictumab (NCT01957007, NCT01973309 and NCT02005315), OMP-54F28, (NCT02069145, NCT02092363 and NCT02050178) and PRI-724 (NCT01606579 and NCT02413853).

\section{Changes in the interleukin 6 signaling pathway}

Inflammation has an important role in PCa pathogenesis by modulating the tumor microenvironment. Among many molecules that are involved in the process of inflammation, interleukin 6 (IL-6) has been studied extensively in the context of PCa biology. IL-6 controls the acute phase response, regulates immune cell differentiation and activation and supports cell proliferation and survival. By binding to a membrane receptor, IL- 6 triggers phosphorylation of Stat 3 by JAK, and concomitant translocation of dimeric Stat3 to the nucleus and regulation of its target genes (Yu et al. 2014).

It is clear that IL-6 plays a role in PCa progression and aggressiveness. For example, the serum levels of this cytokine are high in patients with bone metastases (Shariat et al. 2001, Ara \& DeClerck 2010) and are also associated with shorter survival time in CRPC setting (George et al. 2005). The role of IL-6 in prostate carcinogenesis and progression has been well reviewed by Nguyen et al. (2014a), Culig et al. (2005) and Smith et al. (2001). Involvement of IL-6 in resistance to enzalutamide has been studied in cell line models. The constitutive expression of IL-6 led to persistent activation of Stat3 and loss of sensitivity to enzalutamide (Liu et al. 2014b). The inhibition of Stat3 leads to restoration of sensitivity to enzalutamide. Niclosamide (inhibitor of AR-V7) also inhibits Stat3 phosphorylation and signaling. This drug might therefore be a promising candidate for overcoming enzalutamide resistance and advanced PCa (Liu et al. 2014a).

The IL-6 axis inhibitors have been subjected to clinical investigation in numerous trials. For now, only one IL- 6 axis inhibitor has been used for treatment of PCa. CNTO328, a monoclonal antibody to IL-6, showed minimal activity as monotherapy for treatment of men with CRPC who progressed on docetaxel (Dorff et al. 2010). As the IL-6 axis might be one of the drivers of PCa progression and therapy resistance, development of novel agents and initiation of clinical trials for PCa is needed.

\section{Lineage plasticity and antiandrogen resistance are mediated by SOX 2}

It is becoming clear that cells could switch lineage from a cell type that is sensitive to a certain compound to another cell type that is resistant. Recent publications by $\mathrm{Mu}$ et al. (2017) and Ku et al. (2017) describe the mechanism behind cell lineage plasticity in prostate cancer and how this influences therapy.

Alternations in TP53 and RB1 can be found in 39\% of mCRPC with adenocarcinoma histology and 74\% of mCRPC with neuroendocrine histology, whereas these alternations are only found in 5\% of primary PCa specimens. Upon loss of expression of these two molecules, there is a concomitant increase in SOX2 expression. SOX2 is a transcription factor essential for maintenance of pluripotency and has a role in embryonic and neuronal stem cell maintenance. Activation of SOX2 transcriptional program induces lineage plasticity and allows switch in cell type, which in turn enables cells to adapt under selective pressure of the treatment. Cells expressing SOX 2 would be able to escape AR inhibition by adopting a more neuroendocrine phenotype.

\section{Development of neuroendocrine prostate cancer}

The neuroendocrine phenotype of prostate cancer (NEPC; Fig. 5) has a high metastatic and proliferative potential marked by overexpression of key cell cycle genes (Beltran et al. 2011, Tzelepi et al. 2012). Even though the phenotype of NEPC is complex and can vary greatly (e.g. small-cell carcinoma, large cell carcinoma, paneth cell-like neuroendocrine differentiation, etc.), clinically these tumors are characterized by positive staining for chromogranin, synaptophysin, neuronspecific enolase and CD56 (Abrahamsson 1999, Isshiki et al. 2002, Vashchenko \& Abrahamsson 2005, Evans et al. 2006). On a molecular level NEPC is characterized by low transcriptional activity of the AR, loss of tumor suppressors (RB1, PTEN and TP53), genomic instability, downregulation of REST, changes in IL-6 signaling and 


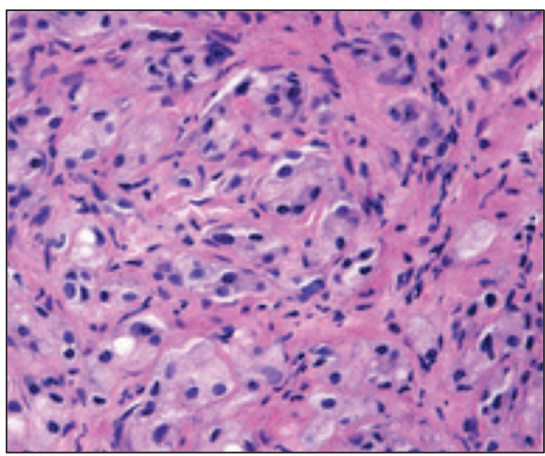

Prostatic adenocarcinoma

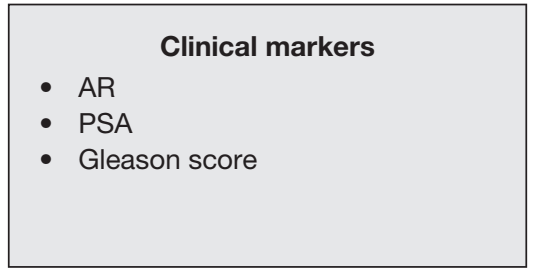

Molecular characteristics

- High AR activity

- TMPRSS2-ERG fusion

- MYC amplifications

- REST high

- PTEN loss

- SPOP mutations

- Loss of tumor suppressors

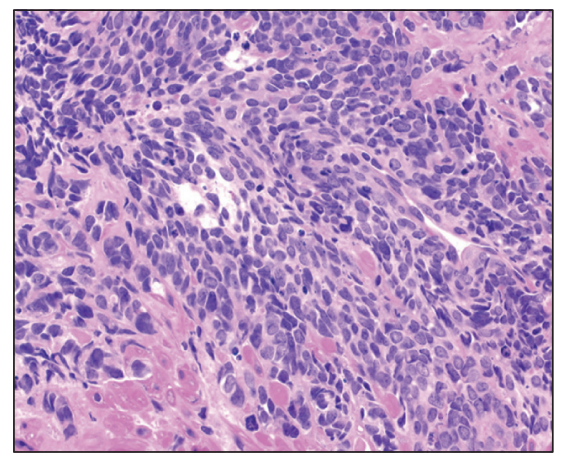

Neuroendocrine prostate cancer

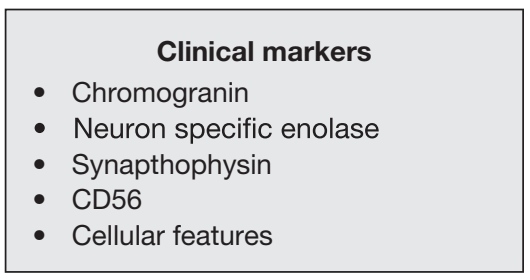

Molecular characteristics

- Low activity of the AR

- Genomic instability

- Changes in IL-6 signaling

- REST low

- MYCN amplifications

- AURKA amplifications

- Loss of tumor suppressors

\section{Figure 5}

Histology and characteristics of prostate adenocarcinoma and neuroendocrine prostate cancer. Prostate adenocarcinoma (image taken from Gordetsky \& Epstein 2016) and

neuroendocrine disease (image taken from Grigore et al. 2015) have different histology and molecular characteristics.
MYCN amplifications (Smith et al. 2008, Lapuk et al. 2012, Beltran \& Rubin 2013, Kani et al. 2013, Logothetis et al. 2013). As these tumors are clinically hormone refractory and resistant to antiandrogens such as enzalutamide, the question is which therapy could be used to treat this aggressive subtype.

Small-cell lung cancer and extrapulmonary smallcell carcinomas are treated with platinum-based chemotherapy; however, due to the lack of prospective data, it is not clear whether this approach is effective in NEPC (Nadal et al. 2014). As NEPC is marked by upregulation of cell cycle genes, one possible way of combating NEPC is targeting the cell cycle machinery. A multi-institutional single-arm, open-label phase II trial evaluating alisertib, inhibitor of AURKA (Kelly et al. 2012), in patients with histologically confirmed or clinically suspected metastatic NEPC (NCT01799278) failed to meet its primary endpoint (Sheahan \& Ellis 2018). On the other hand, data from this trial suggests that in a subset of patients alisertib may be highly effective. A potential alternative therapeutic approach would be to use disulfiram in combination with copper chloride which acts through the increase in reactive oxygen species production and inhibition of DNA methyltransferase and ubiquitin-proteasome pathway (Safi et al. 2014). The use of this drug has shown success in preclinical models of PCa. At this moment, a clinical trial is being set up for evaluating the efficacy of this therapy in patients with CRPC and NEPC (NCT02963051).

\section{General conclusions}

There are many possible mechanisms that have the potential to lead to enzalutamide resistance. The pathways involving the AR signaling are well characterized; however, new concepts are still emerging (e.g. somatically acquired enhancer as a non-coding driver of enzalutamide resistance (Takeda et al. 2018)) The adaptations of cancer cells to the presence of enzalutamide by changes in metabolic pathways (glycolysis, hexosamine), in alternative pathways like autophagy, Wnt, interleukin signaling and even by the development of NEPC clearly shows that we need to do a better job in classifying the advanced disease. Only through such more detailed classifications, patient-tailored rationales for personal or precision medicine can be developed. http://erc.endocrinology-journals.org https://doi.org/10.1530/ERC-17-0136 (c) 2018 Society for Endocrinology Published by Bioscientifica Ltd. Printed in Great Britain 


\section{Declaration of interest}

W Zwart receives grant support from Astellas Pharma. All other authors declare no conflict of interest.

\section{Funding}

F Claessens holds grants from Fonds Wetenschappelijk OnderzoekVlaanderen (GOA9816N, G.0684.12N, G.0830.13N). This work was also supported by the KU Leuven (GOA/15/017) and Kom op tegen Kanker.

\section{References}

Abrahamsson PA 1999 Neuroendocrine differentiation in prostatic carcinoma. Prostate 39 135-148. (https://doi.org/10.1002/(SICI)10970045(19990501)39:2<135::AID-PROS9>3.0.CO;2-S)

Andersen RJ, Mawji NR, Wang J, Wang G, Haile S, Myung J-K, Watt K, Tam T, Yang YC \& Bañuelos CA 2010 Regression of castrate-recurrent prostate cancer by a small-molecule inhibitor of the amino-terminus domain of the androgen receptor. Cancer Cell 17 535-546. (https:// doi.org/10.1016/j.ccr.2010.04.027)

Antonarakis ES, Lu C, Wang H, Luber B, Nakazawa M, Roeser JC, Chen Y, Mohammad TA, Chen Y \& Fedor HL 2014 AR-V7 and resistance to enzalutamide and abiraterone in prostate cancer. New England Journal of Medicine 371 1028-1038. (https://doi.org/10.1056/NEJMoa1315815)

Ara T \& DeClerck YA 2010 Interleukin-6 in bone metastasis and cancer progression. European Journal of Cancer 46 1223-1231. (https://doi. org/10.1016/j.ejca.2010.02.026)

Arora VK, Schenkein E, Murali R, Subudhi SK, Wongvipat J, Balbas MD, Shah N, Cai L, Efstathiou E \& Logothetis C 2013 Glucocorticoid receptor confers resistance to antiandrogens by bypassing androgen receptor blockade. Cell 155 1309-1322. (https://doi.org/10.1016/j. cell.2013.11.012)

Attard G, Reid AH, A'Hern R, Parker C, Oommen NB, Folkerd E, Messiou C, Molife LR, Maier G \& Thompson E 2009 Selective inhibition of CYP17 with abiraterone acetate is highly active in the treatment of castration-resistant prostate cancer. Journal of Clinical Oncology 27 3742-3748. (https://doi.org/10.1200/JCO.2008.20.0642)

Azad AA, Volik SV, Wyatt AW, Haegert A, Le Bihan S, Bell RH, Anderson SA, McConeghy B, Shukin R \& Bazov J 2015 Androgen receptor gene aberrations in circulating cell-free DNA: biomarkers of therapeutic resistance in castration-resistant prostate cancer. Clinical Cancer Research 21 2315-2324. (https://doi.org/10.1158/1078-0432. CCR-14-2666)

Balbas MD, Evans MJ, Hosfield DJ, Wongvipat J, Arora VK, Watson PA, Chen Y, Greene GL, Shen Y \& Sawyers CL 2013 Overcoming mutation-based resistance to antiandrogens with rational drug design. eLife 2 e00499. (https://doi.org/10.7554/eLife.00499)

Beltran H \& Rubin MA 2013 New strategies in prostate cancer: translating genomics into the clinic. Clinical Cancer Research 19 517-523. (https://doi.org/10.1158/1078-0432.CCR-12-1452)

Beltran H, Rickman DS, Park K, Chae SS, Sboner A, MacDonald TY, Wang Y, Sheikh KL, Terry S \& Tagawa ST 2011 Molecular characterization of neuroendocrine prostate cancer and identification of new drug targets. Cancer Discovery 1 487-495. (https://doi. org/10.1158/2159-8290.CD-11-0130)

Bhattacharya B, Mohd Omar MF \& Soong R 2016 The Warburg effect and drug resistance. British Journal of Pharmacology 173 970-979. (https://doi.org/10.1111/bph.13422)

Boutin B, Tajeddine N, Vandersmissen P, Zanou N, Van Schoor M, Mondin L, Courtoy PJ, Tombal B \& Gailly P 2013 Androgen deprivation and androgen receptor competition by bicalutamide induce autophagy of hormone-resistant prostate cancer cells and confer resistance to apoptosis. Prostate 73 1090-1102. (https://doi. org/10.1002/pros.22658)

Byrns MC \& Penning TM 2009 Type 5 17 $\beta$-hydroxysteroid dehydrogenase/prostaglandin F synthase (AKR1C3): role in breast cancer and inhibition by non-steroidal anti-inflammatory drug analogs. Chemico-Biological Interactions 178 221-227. (https://doi. org/10.1016/j.cbi.2008.10.024)

Cai C, Chen S, Ng P, Bubley GJ, Nelson PS, Mostaghel EA, Marck B, Matsumoto AM, Simon NI \& Wang H 2011 Intratumoral de novo steroid synthesis activates androgen receptor in castration-resistant prostate cancer and is upregulated by treatment with CYP17A1 inhibitors. Cancer Research 71 6503-6513. (https://doi. org/10.1158/0008-5472.CAN-11-0532)

Callewaert L, Verrijdt G, Haelens A \& Claessens F 2004 Differential effect of small ubiquitin-like modifier (SUMO)-ylation of the androgen receptor in the control of cooperativity on selective versus canonical response elements. Molecular Endocrinology 18 1438-1449. (https://doi.org/10.1210/me.2003-0313)

Cao B, Qi Y, Zhang G, Xu D, Zhan Y, Alvarez X, Guo Z, Fu X, Plymate SR \& Sartor O 2014 Androgen receptor splice variants activating the full-length receptor in mediating resistance to androgen-directed therapy. Oncotarget 5 1635. (https://doi. org/10.18632/oncotarget.1802)

Chatham JC, Nöt LG, Fülöp N \& Marchase RB 2008 Hexosamine biosynthesis and protein O-glycosylation: the first line of defense against stress, ischemia, and trauma. Shock 29 431-440. (https://doi. org/10.1097/SHK.0b013e3181598bad)

Chen G, Shukeir N, Potti A, Sircar K, Aprikian A, Goltzman D \& Rabbani SA 2004 Up-regulation of Wnt-1 and $\beta$-catenin production in patients with advanced metastatic prostate carcinoma. Cancer 101 1345-1356. (https://doi.org/10.1002/cncr.20518)

Chesire DR, Ewing CM, Sauvageot J, Bova GS \& Isaacs WB 2000 Detection and analysis of $\beta$-catenin mutations in prostate cancer. Prostate 45 323-334. (https://doi.org/10.1002/10970045(20001201)45:4<323::AID-PROS7>3.0.CO;2-W)

Chhipa RR, Wu Y \& Ip C 2011 AMPK-mediated autophagy is a survival mechanism in androgen-dependent prostate cancer cells subjected to androgen deprivation and hypoxia. Cellular Signalling 23 1466-1472. (https://doi.org/10.1016/j.cellsig.2011.04.008)

Cornford P, Bellmunt J, Bolla M, Briers E, De Santis M, Gross T, Henry AM, Joniau S, Lam TB \& Mason MD 2017 EAU-ESTROSIOG guidelines on prostate cancer. Part II: treatment of relapsing, metastatic, and castration-resistant prostate cancer. European Urology 71 630-642. (https://doi.org/10.1016/j. eururo.2016.08.002)

Costello L \& Franklin R 1998 Novel role of zinc in the regulation of prostate citrate metabolism and its implications in prostate cancer. Prostate 35 285-296. (https://doi.org/10.1002/(SICI)10970045(19980601)35:4<285::AID-PROS8>3.0.CO;2-F)

Costello L \& Franklin R 2000 The intermediary metabolism of the prostate: a key to understanding the pathogenesis and progression of prostate malignancy. Oncology 59 269-282. (https://doi. org/10.1159/000012183)

Coutinho I, Day TK, Tilley WD \& Selth LA 2016 Androgen receptor signaling in castration-resistant prostate cancer: a lesson in persistence. Endocrine-Related Cancer 23 T179-T197. (https://doi. org/10.1530/ERC-16-0422)

Cui Y, Nadiminty N, Liu C, Lou W, Schwartz CT \& Gao AC 2014 Upregulation of glucose metabolism by NF-кB2/p52 mediates enzalutamide resistance in castration-resistant prostate cancer cells. Endocrine-Related Cancer 21 435-442. (https://doi.org/10.1530/ERC14-0107)

Culig Z, Steiner H, Bartsch G \& Hobisch A 2005 Interleukin-6 regulation of prostate cancer cell growth. Journal of Cellular Biochemistry 95 497-505. (https://doi.org/10.1002/jcb.20477) (c) 2018 Society for Endocrinology Published by Bioscientifica Ltd. Printed in Great Britain 
Dakubo G, Parr R, Costello L, Franklin R \& Thayer R 2006 Altered metabolism and mitochondrial genome in prostate cancer. Journal of Clinical Pathology 59 10-16. (https://doi.org/10.1136/jcp.2005.027664)

De Bono JS, Logothetis CJ, Molina A, Fizazi K, North S, Chu L, Chi KN, Jones RJ, Goodman OB Jr \& Saad F 2011 Abiraterone and increased survival in metastatic prostate cancer. New England Journal of Medicine 364 1995-2005. (https://doi.org/10.1056/NEJMoa1014618)

Denayer S, Helsen C, Thorrez L, Haelens A \& Claessens F 2010 The rules of DNA recognition by the androgen receptor. Molecular Endocrinology 24 898-913. (https://doi.org/10.1210/me.2009-0310)

Di Vizio D, Morello M, Sotgia F, Pestell RG, Freeman MR \& Lisanti MP 2009 An absence of stromal caveolin-1 is associated with advanced prostate cancer, metastatic disease spread and epithelial Akt activation. Cell Cycle 8 2420-2424. (https://doi.org/10.4161/ cc.8.15.9116)

Dorff TB, Goldman B, Pinski JK, Mack PC, Lara PN, Van Veldhuizen PJ, Quinn DI, Vogelzang NJ, Thompson IM \& Hussain MH 2010 Clinical and correlative results of SWOG S0354: a phase II trial of CNTO328 (siltuximab), a monoclonal antibody against interleukin-6, in chemotherapy-pretreated patients with castration-resistant prostate cancer. Clinical Cancer Research 16 3028-3034. (https://doi. org/10.1158/1078-0432.CCR-09-3122)

Dwarakanath B, Singh D, Banerji AK, Sarin R, Venkataramana N, Jalali R, Vishwanath P, Mohanti B, Tripathi R \& Kalia V 2009 Clinical studies for improving radiotherapy with 2-deoxy-D-glucose: present status and future prospects. Journal of Cancer Research and Therapeutics 521. (https://doi.org/10.4103/0973-1482.55136)

Evans AJ, Humphrey PA, Belani J, van der Kwast TH \& Srigley JR 2006 Large cell neuroendocrine carcinoma of prostate: a clinicopathologic summary of 7 cases of a rare manifestation of advanced prostate cancer. American Journal of Surgical Pathology 30 684-693. (https:// doi.org/10.1097/00000478-200606000-00003)

Fosså S, Slee PT, Brausi M, Horenblas S, Hall R, Hetherington J, Aaronson N, De Prijck L \& Collette L 2001 Flutamide versus prednisone in patients with prostate cancer symptomatically progressing after androgen-ablative therapy: a phase III study of the European organization for research and treatment of cancer genitourinary group. Journal of Clinical Oncology 19 62-71. (https:// doi.org/10.1200/JCO.2001.19.1.62)

Fung K-M, Samara E, Wong C, Metwalli A, Krlin R, Bane B, Liu C, Yang J, Pitha J \& Culkin D 2006 Increased expression of type 2 $3 \alpha$-hydroxysteroid dehydrogenase/type 5 17 $\beta$-hydroxysteroid dehydrogenase (AKR1C3) and its relationship with androgen receptor in prostate carcinoma. Endocrine-Related Cancer 13 169-180. (https://doi.org/10.1677/erc.1.01048)

Gatenby RA \& Gillies RJ 2004 Why do cancers have high aerobic glycolysis? Nature Reviews Cancer 4 891-899. (https://doi. org/10.1038/nrc1478)

George DJ, Halabi S, Shepard TF, Sanford B, Vogelzang NJ, Small EJ \& Kantoff PW 2005 The prognostic significance of plasma interleukin-6 levels in patients with metastatic hormone-refractory prostate cancer: results from cancer and leukemia group B 9480. Clinical Cancer Research 11 1815-1820. (https://doi.org/10.1158/1078-0432. CCR-04-1560)

Gómez-Orte E, Sáenz-Narciso B, Moreno S \& Cabello J 2013 Multiple functions of the noncanonical Wnt pathway. Trends in Genetics 29 545-553. (https://doi.org/10.1016/j.tig.2013.06.003)

Gordetsky J \& Epstein J 2016 Grading of prostatic adenocarcinoma: current state and prognostic implications. Diagnostic Pathology 1125. (https://doi.org/10.1186/s13000-016-0478-2)

Grigore AD, Ben-Jacob E \& Farach-Carson MC 2015 Prostate cancer and neuroendocrine differentiation: more neuronal, less endocrine? Frontiers in Oncology 5 37. (https://doi.org/10.3389/fonc.2015.00037)

Grossmann ME, Huang H \& Tindall DJ 2001 Androgen receptor signaling in androgen-refractory prostate cancer. Journal of the
National Cancer Institute 93 1687-1697. (https://doi.org/10.1093/ jnci/93.22.1687)

Gupta S, Farooque A, Adhikari J, Singh S \& Dwarakanath B 2009 Enhancement of radiation and chemotherapeutic drug responses by 2-deoxy-D-glucose in animal tumors. Journal of Cancer Research and Therapeutics 5 16. (https://doi.org/10.4103/0973-1482.55135)

Haelens A, Tanner T, Denayer S, Callewaert L \& Claessens F 2007 The hinge region regulates DNA binding, nuclear translocation, and transactivation of the androgen receptor. Cancer Research $\mathbf{6 7}$ 4514-4523. (https://doi.org/10.1158/0008-5472.CAN-06-1701)

Hamid ARA, Pfeiffer MJ, Verhaegh G, Schaafsma H, Brandt A, Sweep F, Sedelaar JP \& Schalken JA 2012 Aldo-keto reductase family 1 member C3 (AKR1C3) is a biomarker and therapeutic target for castration-resistant prostate cancer. Molecular Medicine 181449. (https://doi.org/10.2119/molmed.2012.00296)

Isshiki S, Akakura K, Komiya A, Suzuki H, Kamiya N \& Ito H 2002 Chromogranin A concentration as a serum marker to predict prognosis after endocrine therapy for prostate cancer. Journal of Urology 167 512-515. (https://doi.org/10.1016/S0022$5347(01) 69075-\mathrm{X})$

Itkonen HM, Gorad SS, Duveau DY, Martin SE, Barkovskaya A, Bathen TF, Moestue SA \& Mills IG 2016 Inhibition of O-GlcNAc transferase activity reprograms prostate cancer cell metabolism. Oncotarget 7 12464-12476. (https://doi.org/10.18632/ oncotarget.7039)

Joseph JD, Lu N, Qian J, Sensintaffar J, Shao G, Brigham D, Moon M, Maneval EC, Chen I \& Darimont B 2013 A clinically relevant androgen receptor mutation confers resistance to second-generation antiandrogens enzalutamide and ARN-509. Cancer Discovery 3 1020-1029. (https://doi.org/10.1158/2159-8290.CD-13-0226)

Kahn M 2014 Can we safely target the WNT pathway? Nature Reviews Drug Discovery 13 513-532. (https://doi.org/10.1038/nrd4233)

Kamigaito T, Okaneya T, Kawakubo M, Shimojo H, Nishizawa O \& Nakayama J 2014 Overexpression of O-GlcNAc by prostate cancer cells is significantly associated with poor prognosis of patients. Prostate Cancer and Prostatic Diseases 17 18-22. (https://doi. org/10.1038/pcan.2013.56)

Kani K, Malihi PD, Jiang Y, Wang H, Wang Y, Ruderman DL, Agus DB, Mallick P \& Gross ME 2013 Anterior gradient 2 (AGR2): blood-based biomarker elevated in metastatic prostate cancer associated with the neuroendocrine phenotype. Prostate 73 306-315. (https://doi. org/10.1002/pros.22569)

Kaushik AK, Shojaie A, Panzitt K, Sonavane R, Venghatakrishnan H Manikkam M, Zaslavsky A, Putluri V, Vasu VT \& Zhang Y 2016 Inhibition of the hexosamine biosynthetic pathway promotes castration-resistant prostate cancer. Nature Communications 711612. (https://doi.org/10.1038/ncomms11612)

Kelly KR, Nawrocki ST, Espitia CM, Zhang M, Yang JJ, Padmanabhan S, Ecsedy J, Giles FJ \& Carew JS 2012 Targeting Aurora A kinase activity with the investigational agent alisertib increases the efficacy of cytarabine through a FOXO-dependent mechanism. International Journal of Cancer 131 2693-2703. (https://doi.org/10.1002/ijc.27579)

Knuuttila M, Mehmood A, Mäki-Jouppila J, Ryberg H, Taimen P, Knaapila J, Ettala O, Bostrom PJ, Ohlsson C \& Venäläinen MS 2018 Intratumoral androgen levels are linked to TMPRSS2-ERG fusion in prostate cancer. Endocrine-Related Cancer 25 807-819. (https://doi. org/10.1530/ERC-18-0148)

Korpal M, Korn JM, Gao X, Rakiec DP, Ruddy DA, Doshi S, Yuan J, Kovats SG, Kim S \& Cooke VG 2013 An F876L mutation in androgen receptor confers genetic and phenotypic resistance to MDV3100 (enzalutamide). Cancer Discovery 3 1030-1043. (https:// doi.org/10.1158/2159-8290.CD-13-0142)

Ku SY, Rosario S, Wang Y, Mu P, Seshadri M, Goodrich ZW, Goodrich MM, Labbé DP, Gomez EC \& Wang J 2017 Rb1 and Trp53 cooperate to suppress prostate cancer lineage plasticity, metastasis,
(2) 2018 Society for Endocrinology Published by Bioscientifica Ltd. Printed in Great Britain 
and antiandrogen resistance. Science 355 78-83. (https://doi. org/10.1126/science.aah4199)

Lallous N, Volik SV, Awrey S, Leblanc E, Tse R, Murillo J, Singh K, Azad AA, Wyatt AW \& LeBihan S 2016 Functional analysis of androgen receptor mutations that confer anti-androgen resistance identified in circulating cell-free DNA from prostate cancer patients. Genome Biology 17 10. (https://doi.org/10.1186/s13059-015-0864-1)

Lapuk AV, Wu C, Wyatt AW, McPherson A, McConeghy BJ, Brahmbhatt S, Mo F, Zoubeidi A, Anderson S \& Bell RH 2012 From sequence to molecular pathology, and a mechanism driving the neuroendocrine phenotype in prostate cancer. Journal of Pathology 227 286-297. (https://doi.org/10.1002/path.4047)

Lee GT, Kang DI, Ha Y-S, Jung YS, Chung J, Min K, Kim TH, Moon KH, Chung JM \& Lee DH 2014 Prostate cancer bone metastases acquire resistance to androgen deprivation via WNT5A-mediated BMP-6 induction. British Journal of Cancer 110 1634. (https://doi. org/10.1038/bjc.2014.23)

Lee E, Ha S \& Logan SK 2015 Divergent androgen receptor and betacatenin signaling in prostate cancer cells. PLoS ONE 10 e0141589. (https://doi.org/10.1371/journal.pone.0141589)

Li M, Jiang X, Liu D, Na Y, Gao GF \& Xi Z 2008 Autophagy protects LNCaP cells under androgen deprivation conditions. Autophagy 4 54-60. (https://doi.org/10.4161/auto.5209)

Li Y, Chan SC, Brand LJ, Hwang TH, Silverstein KA \& Dehm SM 2013 Androgen receptor splice variants mediate enzalutamide resistance in castration-resistant prostate cancer cell lines. Cancer Research $\mathbf{7 3}$ 483-489. (https://doi.org/10.1158/0008-5472.CAN-12-3630)

Li J, Alyamani M, Zhang A, Chang K-H, Berk M, Li Z, Zhu Z, Petro M, Magi-Galluzzi C \& Taplin M-E 2017 Aberrant corticosteroid metabolism in tumor cells enables GR takeover in enzalutamide resistant prostate cancer. eLife 6 e20183. (https://doi.org/10.7554/ eLife.20183)

Lin H-K, Jez JM, Schlegel BP, Peehl DM, Pachter JA \& Penning TM 1997 Expression and characterization of recombinant type 2 $3 \alpha$-hydroxysteroid dehydrogenase (HSD) from human prostate: demonstration of bifunctional $3 \alpha / 17 \beta$-HSD activity and cellular distribution. Molecular Endocrinology 11 1971-1984. (https://doi. org/10.1210/mend.11.13.0026)

Liu C, Lou W, Zhu Y, Nadiminty N, Schwartz CT, Evans CP \& Gao AC $2014 a$ Niclosamide inhibits androgen receptor variants expression and overcomes enzalutamide resistance in castration-resistant prostate cancer. Clinical Cancer Research 20 3198-3210. (https://doi. org/10.1158/1078-0432.CCR-13-3296)

Liu C, Zhu Y, Lou W, Cui Y, Evans CP \& Gao AC 2014b Inhibition of constitutively active Stat 3 reverses enzalutamide resistance in LNCaP derivative prostate cancer cells. Prostate 74 201-209. (https://doi. org/10.1002/pros.22741)

Liu C, Lou W, Zhu Y, Yang JC, Nadiminty N, Gaikwad NW, Evans CP \& Gao AC 2015 Intracrine androgens and AKR1C3 activation confer resistance to enzalutamide in prostate cancer. Cancer Research $\mathbf{7 5}$ 1413-1422. (https://doi.org/10.1158/0008-5472.CAN-14-3080)

Locke JA, Guns ES, Lubik AA, Adomat HH, Hendy SC, Wood CA, Ettinger SL, Gleave ME \& Nelson CC 2008 Androgen levels increase by intratumoral de novo steroidogenesis during progression of castration-resistant prostate cancer. Cancer Research 68 6407-6415. (https://doi.org/10.1158/0008-5472.CAN-07-5997)

Logan CY \& Nusse R 2004 The Wnt signaling pathway in development and disease. Annual Review of Cell and Developmental Biology 20 781-810. (https://doi.org/10.1146/annurev.cellbio.20.010403.113126)

Logothetis CJ, Gallick GE, Maity SN, Kim J, Aparicio A, Efstathiou E \& Lin S-H 2013 Molecular classification of prostate cancer progression: foundation for marker-driven treatment of prostate cancer. Cancer Discovery 3 849-861. (https://doi.org/10.1158/2159-8290.CD-120460)

Lunt SY \& Vander Heiden MG 2011 Aerobic glycolysis: meeting the metabolic requirements of cell proliferation. Annual Review of Cell and Developmental Biology 27 441-464. (https://doi.org/10.1146/ annurev-cellbio-092910-154237)

Luo J, Attard G, Balk SP, Bevan C, Burnstein K, Cato L, Cherkasov A, De Bono JS, Dong Y \& Gao AC 2017 Role of androgen receptor variants in prostate cancer: report from the 2017 Mission Androgen Receptor Variants meeting. European Urology 73 715-723. (https://doi. org/10.1016/j.eururo.2017.11.038)

Lynch TP, Ferrer CM, Jackson SR, Shahriari KS, Vosseller K \& Reginato MJ 2012 Critical role of O-Linked $\beta$-N-acetylglucosamine transferase in prostate cancer invasion, angiogenesis, and metastasis. Journal of Biological Chemistry 287 11070-11081. (https://doi. org/10.1074/jbc.M111.302547)

Ma Z \& Vosseller K 2014 Cancer metabolism and elevated O-GlcNAc in oncogenic signaling. Journal of Biological Chemistry 289 34457-34465. (https://doi.org/10.1074/jbc.R114.577718)

Matsuura K, Shiraishi H, Hara A, Sato K, Deyashiki Y, Ninomiya M \& Sakai S 1998 Identification of a principal mRNA species for human $3 \alpha$-hydroxysteroid dehydrogenase isoform (AKR1C3) that exhibits high prostaglandin D2 11-ketoreductase activity. Journal of Biochemistry 124 940-946. (https://doi.org/10.1093/oxfordjournals. jbchem.a022211)

Miyamoto DT, Zheng Y, Wittner BS, Lee RJ, Zhu H, Broderick KT, Desai R, Fox DB, Brannigan BW \& Trautwein J 2015 RNA-Seq of single prostate CTCs implicates noncanonical Wnt signaling in antiandrogen resistance. Science 349 1351-1356. (https://doi. org/10.1126/science.aab0917)

Montgomery B, Cheng HH, Drechsler J \& Mostaghel EA 2014 Glucocorticoids and prostate cancer treatment: friend or foe? Asian Journal of Andrology 16 354. (https://doi.org/10.4103/1008682X.125392)

Mu P, Zhang Z, Benelli M, Karthaus WR, Hoover E, Chen C-C, Wongvipat J, Ku S-Y, Gao D \& Cao Z 2017 SOX2 promotes lineage plasticity and antiandrogen resistance in TP53-and RB1-deficient prostate cancer. Science 355 84-88. (https://doi.org/10.1126/science. aah4307)

Munkley J, Mills IG \& Elliott DJ 2016 The role of glycans in the development and progression of prostate cancer. Nature Reviews Urology 13 324. (https://doi.org/10.1038/nrurol.2016.65)

Nadal R, Schweizer M, Kryvenko ON, Epstein JI \& Eisenberger MA 2014 Small cell carcinoma of the prostate. Nature Reviews Urology $\mathbf{1 1}$ 213-219. (https://doi.org/10.1038/nrurol.2014.21)

Nadal M, Prekovic S, Gallastegui N, Helsen C, Abella M, Zielinska K, Gay M, Vilaseca M, Taulès M \& Houtsmuller AB 2017 Structure of the homodimeric androgen receptor ligand-binding domain. Nature Communications 8 14388. (https://doi.org/10.1038/ ncomms14388)

Nguyen DP, Li J \& Tewari AK 2014a Inflammation and prostate cancer: the role of interleukin 6 (IL-6). BJU International 113 986-992. (https://doi.org/10.1111/bju.12452)

Nguyen H, Yang J, Kung H-J, Shi X-B, Tilki D, Lara PN, White RD, Gao AC \& Evans CP 2014b Targeting autophagy overcomes Enzalutamide resistance in castration-resistant prostate cancer cells and improves therapeutic response in a xenograft model. Oncogene 33 4521-4530. (https://doi.org/10.1038/onc.2014.25)

Nishimura K, Nonomura N, Satoh E, Harada Y, Nakayama M, Tokizane T, Fukui T, Ono Y, Inoue H \& Shin M 2001 Potential mechanism for the effects of dexamethasone on growth of androgen-independent prostate cancer. Journal of the National Cancer Institute 93 1739-1746. (https://doi.org/10.1093/jnci/93.22.1739)

Njar VC \& Brodie AM 2015 Discovery and development of Galeterone (TOK-001 or VN/124-1) for the treatment of all stages of prostate cancer. Journal of Medicinal Chemistry 58 2077-2087. (https://doi. org/10.1021/jm501239f)

Parikh M, Hyunh JC, Lara P, Pan C-X, Robles D \& Evans CP 2018 Enzalutamide and metformin combination therapy to overcome autophagy resistance in castration resistant prostate cancer (CRPC):
(2) 2018 Society for Endocrinology Published by Bioscientifica Ltd. Printed in Great Britain 
current results from a phase I study. Journal of Clinical Oncology 36 (Supplement 6) 281.(doi:10.1200/JCO.2018.36.6_suppl.281)

Pertega-Gomes N, Felisbino S, Massie CE, Vizcaino JR, Coelho R, Sandi C, Simoes-Sousa S, Jurmeister S, Ramos-Montoya A \& Asim M 2015 A glycolytic phenotype is associated with prostate cancer progression and aggressiveness: a role for monocarboxylate transporters as metabolic targets for therapy. Journal of Pathology 236 517-530.

Pfeiffer MJ, Smit FP, Sedelaar JP \& Schalken JA 2011 Steroidogenic enzymes and stem cell markers are upregulated during androgen deprivation in prostate cancer. Molecular Medicine 17 657. (https:// doi.org/10.1007/s00894-010-0756-y)

Prekovic S, van Royen ME, Voet AR, Geverts B, Houtman R, Melchers D Zhang KY, Van den Broeck T, Smeets E \& Spans L 2016 The effect of F877L and T878A mutations on androgen receptor response to Enzalutamide. Molecular Cancer Therapeutics 15 1702-1712. (https:// doi.org/10.1158/1535-7163.MCT-15-0892)

Prekovic S, Van den Broeck T, Moris L, Smeets E, Claessens F, Joniau S, Helsen C \& Attard G 2017 Treatment-induced changes in the androgen receptor axis: liquid biopsies as diagnostic/prognostic tools for prostate cancer. Molecular and Cellular Endocrinology 462 56-63. (https://doi.org/10.1016/j.mce.2017.08.020)

Roberts CT Jr 2004 IGF-1 and prostate cancer. In Biology of IGF-1: Its Interaction with Insulin in Health and Malignant States, Novartis Foundation Symposium 2004, p 193-199.

Robinson D, Van Allen EM, Wu Y-M, Schultz N, Lonigro RJ, Mosquera JM, Montgomery B, Taplin M-E, Pritchard CC \& Attard G 2015 Integrative clinical genomics of advanced prostate cancer. Cell $16 \mathbf{1}$ 1215-1228. (https://doi.org/10.1016/j.cell.2015.05.001)

Rothermundt C, Hayoz S, Templeton AJ, Winterhalder R, Strebel RT, Bärtschi D, Pollak M, Lui L, Endt K \& Schiess R 2014 Metformin in chemotherapy-naive castration-resistant prostate cancer: a multicenter phase 2 trial (SAKK 08/09). European Urology 66 468-474. (https://doi.org/10.1016/j.eururo.2013.12.057)

Ryan CJ, Smith MR, De Bono JS, Molina A, Logothetis CJ, De Souza P, Fizazi K, Mainwaring P, Piulats JM \& Ng S 2013 Abiraterone in metastatic prostate cancer without previous chemotherapy. New England Journal of Medicine 368 138-148. (https://doi.org/10.1056/ NEJMoa1209096)

Safi R, Nelson ER, Chitneni SK, Franz KJ, George DJ, Zalutsky MR \& McDonnell DP 2014 Copper signaling axis as a target for prostate cancer therapeutics. Cancer Research 74 5819-5831. (https://doi. org/10.1158/0008-5472.CAN-13-3527)

Sahu B, Laakso M, Pihlajamaa P, Ovaska K, Sinielnikov I, Hautaniemi S \& Jänne OA 2013 FoxA1 specifies unique androgen and glucocorticoid receptor binding events in prostate cancer cells. Cancer Research 73 1570-1580. (https://doi.org/10.1158/0008-5472. CAN-12-2350)

Sales KJ, Milne SA, Williams AR, Anderson RA \& Jabbour HN 2004 Expression, localization, and signaling of prostaglandin F2 $\alpha$ receptor in human endometrial adenocarcinoma: regulation of proliferation by activation of the epidermal growth factor receptor and mitogenactivated protein kinase signaling pathways. Journal of Clinical Endocrinology and Metabolism 89 986-993. (https://doi.org/10.1210/ jc.2003-031434)

Sartor O \& de Bono JS 2018 Metastatic prostate cancer. New England Journal of Medicine 378 645-657. (https://doi.org/10.1056/ NEJMra1701695)

Schoenmakers E, Philippe A, Verrijdt G, Peeters B, Verhoeven G, Rombauts W \& Claessens F 1999 Differential DNA binding by the androgen and glucocorticoid receptors involves the second $\mathrm{Zn}$-finger and a C-terminal extension of the DNA-binding domains. Biochemical Journal 341 515-521. (https://doi.org/10.1042/ bj3410515)

Schoenmakers E, Verrijdt G, Peeters B, Verhoeven G, Rombauts W \& Claessens F 2000 Differences in DNA binding characteristics of the androgen and glucocorticoid receptors can determine hormonespecific responses. Journal of Biological Chemistry 275 12290-12297. (https://doi.org/10.1074/jbc.275.16.12290)

Seitz AK, Thoene S, Bietenbeck A, Nawroth R, Tauber R, Thalgott M, Schmid S, Secci R, Retz M \& Gschwend JE 2017 AR-V7 in peripheral whole blood of patients with castration-resistant prostate cancer: association with treatment-specific outcome under abiraterone and enzalutamide. European Urology 72 828-834. (https://doi. org/10.1016/j.eururo.2017.07.024)

Shaffer PL, Jivan A, Dollins DE, Claessens F \& Gewirth DT 2004 Structural basis of androgen receptor binding to selective androgen response elements. PNAS 101 4758-4763. (https://doi.org/10.1073/ pnas.0401123101)

Shariat SF, Andrews B, Kattan MW, Kim J, Wheeler TM \& Slawin KM 2001 Plasma levels of interleukin-6 and its soluble receptor are associated with prostate cancer progression and metastasis. Urology 58 1008-1015. (https://doi.org/10.1016/S0090-4295(01)01405-4)

Sheahan AV \& Ellis L 2018 Epigenetic reprogramming: a key mechanism driving therapeutic resistance. In Urologic Oncology: Seminars and Original Investigations. New York, NY, USA: Elsevier. (https://doi. org/10.1016/j.urolonc.2017.12.021)

Smith PC, Hobisch A, Lin D-L, Culig Z \& Keller ET 2001 Interleukin-6 and prostate cancer progression. Cytokine and Growth Factor Reviews 12 33-40. (https://doi.org/10.1016/S1359-6101(00)00021-6)

Smith ND, Schulze-Hoepfner FT, Veliceasa D, Filleur S, Shareef S, Huang L, Huang X-M \& Volpert OV 2008 Pigment epitheliumderived factor and interleukin- 6 control prostate neuroendocrine differentiation via feed-forward mechanism. Journal of Urology 179 2427-2434. (https://doi.org/10.1016/j.juro.2008.01.081)

Sparks C \& Guertin D 2010 Targeting mTOR: prospects for mTOR complex 2 inhibitors in cancer therapy. Oncogene 29 3733-3744. (https://doi.org/10.1038/onc.2010.139)

Stanbrough M, Bubley GJ, Ross K, Golub TR, Rubin MA, Penning TM, Febbo PG \& Balk SP 2006 Increased expression of genes converting adrenal androgens to testosterone in androgen-independent prostate cancer. Cancer Research 66 2815-2825. (https://doi.org/10.1158/00085472.CAN-05-4000)

Statz CM, Patterson SE \& Mockus SM 2016 mTOR inhibitors in castration-resistant prostate cancer: a systematic review. Targeted Oncology 12 47-59. (https://doi.org/10.1007/s11523-016-0453-6)

Stein M, Lin H, Jeyamohan C, Dvorzhinski D, Gounder M, Bray K, Eddy S, Goodin S, White E \& DiPaola RS 2010 Targeting tumor metabolism with 2-deoxyglucose in patients with castrate-resistant prostate cancer and advanced malignancies. Prostate 70 1388-1394. (https://doi.org/10.1002/pros.21172)

Storlie JA, Buckner JC, Wiseman GA, Burch PA, Hartmann LC \& Richardson RL 1995 Prostate specific antigen levels and clinical response to low dose dexamethasone for hormone-refractory metastatic prostate carcinoma. Cancer 76 96-100. (https://doi. org/10.1002/1097-0142(19950701)76:1<96::AIDCNCR2820760114>3.0.CO;2-E)

Takahashi S, Watanabe T, Okada M, Inoue K, Ueda T, Takada I, Watabe T, Yamamoto Y, Fukuda T \& Nakamura T 2011 Noncanonical Wnt signaling mediates androgen-dependent tumor growth in a mouse model of prostate cancer. PNAS 108 4938-4943. (https://doi. org/10.1073/pnas.1014850108)

Takeda DY, Spisák S, Seo J-H, Bell C, O’Connor E, Korthauer K, Ribli D, Csabai I, Solymosi N \& Szállási Z 2018 A somatically acquired enhancer of the androgen receptor is a noncoding driver in advanced prostate cancer. Cell 172 422-432. (https://doi. org/10.1016/j.cell.2018.05.037)

Tannock IF, Osoba D, Stockler MR, Ernst DS, Neville AJ, Moore MJ, Armitage GR, Wilson JJ, Venner PM \& Coppin C 1996 Chemotherapy with mitoxantrone plus prednisone or prednisone alone for symptomatic hormone-resistant prostate cancer: a Canadian randomized trial with palliative end points. Journal of
(2) 2018 Society for Endocrinology Published by Bioscientifica Ltd. Printed in Great Britain 
Clinical Oncology 14 1756-1764. (https://doi.org/10.1200/

JCO.1996.14.6.1756)

Taplin M-E, Bubley GJ, Ko Y-J, Small EJ, Upton M, Rajeshkumar B \& Balk SP 1999 Selection for androgen receptor mutations in prostate cancers treated with androgen antagonist. Cancer Research $\mathbf{5 9}$ 2511-2515.

Trapannone R, Rafie K \& van Aalten DM 2016 O-GlcNAc transferase inhibitors: current tools and future challenges. Biochemical Society Transactions 44 88-93. (https://doi.org/10.1042/BST20150189)

Tummala R, Lou W, Gao AC \& Nadiminty N 2017 Quercetin targets hnRNPA1 to overcome enzalutamide resistance in prostate cancer cells. Molecular Cancer Therapeutics 16 2770-2779. (https://doi. org/10.1158/1535-7163.MCT-17-0030)

Tzelepi V, Zhang J, Lu J-F, Kleb B, Wu G, Wan X, Hoang A, Efstathiou E, Sircar K \& Navone NM 2012 Modeling a lethal prostate cancer variant with small-cell carcinoma features. Clinical Cancer Research 18 666-677. (https://doi.org/10.1158/1078-0432.CCR-11-1867)

Vashchenko N \& Abrahamsson P-A 2005 Neuroendocrine differentiation in prostate cancer: implications for new treatment modalities. European Urology 47 147-155. (https://doi.org/10.1016/j. eururo.2004.09.007)

Verma K, Zang T, Gupta N, Penning TM \& Trippier PC 2016 Selective AKR1C3 inhibitors potentiate chemotherapeutic activity in multiple acute myeloid leukemia (AML) cell lines. ACS Medicinal Chemistry Letters 7 774-779. (https://doi.org/10.1021/ acsmedchemlett.6b00163)

Wako K, Kawasaki T, Yamana K, Suzuki K, Jiang S, Umezu H, Nishiyama T, Takahashi K, Hamakubo T \& Kodama T 2008 Expression of androgen receptor through androgen-converting enzymes is associated with biological aggressiveness in prostate cancer. Journal of Clinical Pathology 61 448-454. (https://doi. org/10.1136/jcp.2007.050906)

Warburg OH \& Dickens F 1930 The metabolism of tumours: investigations from the Kaiser Wilhelm Institute for Biology, Berlin-Dahlem. London, UK: Constable and Company.

Watson PA, Chen YF, Balbas MD, Wongvipat J, Socci ND, Viale A, Kim K \& Sawyers CL 2010 Constitutively active androgen receptor splice variants expressed in castration-resistant prostate cancer require fulllength androgen receptor. PNAS 107 16759-16765. (https://doi. org/10.1073/pnas.1012443107)

Watson PA, Arora VK \& Sawyers CL 2015 Emerging mechanisms of resistance to androgen receptor inhibitors in prostate cancer. Nature Reviews Cancer 15 701. (https://doi.org/10.1038/nrc4016)

Wyatt AW, Azad AA, Volik SV, Annala M, Beja K, McConeghy B, Haegert A, Warner EW, Mo F \& Brahmbhatt S 2016 Genomic alterations in cell-free DNA and enzalutamide resistance in castration-resistant prostate cancer. JAMA Oncology 2 1598-1606. (https://doi.org/10.1001/jamaoncol.2016.0494)

Yano A, Fujii Y, Iwai A, Kageyama Y \& Kihara K 2006 Glucocorticoids suppress tumor angiogenesis and in vivo growth of prostate cancer cells. Clinical Cancer Research 12 3003-3009. (https://doi. org/10.1158/1078-0432.CCR-05-2085)

Yemelyanov A, Czwornog J, Chebotaev D, Karseladze A, Kulevitch E, Yang X \& Budunova I 2007 Tumor suppressor activity of glucocorticoid receptor in the prostate. Oncogene 26 1885-1896. (https://doi.org/10.1038/sj.onc.1209991)

Yu H, Lee H, Herrmann A, Buettner R \& Jove R 2014 Revisiting STAT3 signalling in cancer: new and unexpected biological functions. Nature Reviews Cancer 14 736-746. (https://doi.org/10.1038/ $\operatorname{nrc3818)}$

Received in final form 22 June 2018

Accepted 5 July 2018 (c) 2018 Society for Endocrinology Published by Bioscientifica Ltd. Printed in Great Britain 